\title{
Young Vasospastic Angina Patients Less Than 20 Years Old
}

\author{
Shozo Sueda, MD
}

Background: Japanese Circulation Society (JCS) guidelines do not include adolescents with coronary artery spasm.

Methods and Results: We recruited 18 adolescents less than 20 years old with vasospastic angina (VSA): 11 were Japanese and 3 had chest symptoms for $>12$ months before admission. ST-segment elevation was observed in 11 patients and none of the 18 patients had a fixed stenosis. Spasm provocation tests were performed in 9 patients and two-thirds had multiple spasms; 6 suffered from acute myocardial infarction and ventricular fibrillation occurred in 2 patients; 1 patient died and the remaining 17 patents survived.

Conclusions: Clinical status of adolescents with VSA was as severe as in adults with refractory VSA. Cardiologists should cooperate with pediatricians to diagnose and treat adolescents with VSA. There is a need to establish the additional issues for adolescents with coronary spasm in the JCS guidelines.

Key Words: Adolescents; Cardiologists; Guidelines; Pediatricians; Vasospastic angina

$\mathbf{C}$ oronary artery spasm may be involved in the pathogenesis of various cardiac diseases such as sudden cardiac death, acute myocardial infarction, fatal arrhythmias, heart failure, angina pectoris, atypical chest pain and other disorders. ${ }^{1-5}$ The majority of patients with vasospastic angina (VSA) are older than 50 or 60 years, but occasionally adolescents present with VSA in the clinic. However, the particular issues of adolescent VSA are not covered by the Japanese Circulation Society (JCS) guidelines. ${ }^{6}$

Therefore, we recruited patients less than 20 years old with VSA and investigated their real-world data.

\section{Methods}

We recruited the data for 18 patients less than 20 years old with VSA reported in the PubMed database; ${ }^{7-21}$ As shown in Table 1, 11 were less than 15 years old; 10 were male and 8 were female; 11 patients were Japanese, and the other 7 patients were included 3 Americans, 1 Turk and 1 Chinese. None of the 18 patients had hypertension or diabetes mellitus/dyslipidemia. Coronary artery stenosis was not found in any of the 18 patients.

\section{Duration of VSA Before Admission}

Sudden onset occurred in 13 patients, who had emergency admission by ambulance, and 5 patients had a history of chest symptoms before admission; 3 patients had chest symptoms for more than 12 months. The longest duration of chest symptoms before diagnosis was 36 months.

\section{Chief Complaint}

Chest pain or chest oppression was the chief complaint in
12 patients and cardiopulmonary arrest was the first event in 2 patients. In 1 case the patient only had toothache without chest symptoms and another patient had dyspnea on effort without chest pain or oppression.

\section{Passive Smoking}

In 1 case the patient had an obvious passive smoking history because both parents had a history of smoking for more than 18 years, even at home. Another patient did not have a history of passive smoking, but we could not obtain definitive history of passive smoking for the remaining 16 patients (Table 1).

\section{Time and Duration of Chest Pain}

Chest symptoms occurred at rest in 7 patients, 4 patients complained of chest symptoms on effort and 2 patients had chest symptoms both at rest and on effort. Chest pain occurred in the daytime in 7 patients, 3 patients complained of chest pain at nighttime, and 3 patients had chest pain attacks both day and night. The duration of chest pain was a few minutes to $3 \mathrm{~h} ; 5$ patients had $<10 \mathrm{~min}$ of angina whereas 4 patents had $>60$ min of chest pain.

\section{ECG Findings on Admission}

Ischemic ECG changes were observed in 14 patients, STsegment elevation was observed in 11 patients, and 1 patient had ST-segment depression on admission. Ischemic ECG changes in inferior leads were recognized in 6 patients, and anterolateral ischemia was found in 9 patients.

Elevation of Cardiac Enzymes and Wall Motion Abnormality As shown in Table 2, elevated creatine phosphokinase (CPK)

Received May 13, 2019; revised manuscript received June 21, 2019; accepted June 25, 2019; J-STAGE Advance Publication released online August 2, 2019 Time for primary review: 21 days

Department of Cardiology, Ehime Niihama Prefectural Hospital, Niihama, Japan

Mailing address: Shozo Sueda, MD, The Department of Cardiology, Ehime Niihama Prefectural Hospital, Hongou 3 choume 1-1, Niiham 792-0042, Japan. E-mail: EZF03146@nifty.com

ISSN-1346-9843 All rights are reserved to the Japanese Circulation Society. For permissions, please e-mail: cj@j-circ.or.jp 


\begin{tabular}{|c|c|c|c|c|c|c|}
\hline No. & $\begin{array}{l}\text { Author } \\
\text { (Year) }\end{array}$ & $\begin{array}{c}\text { Age } \\
\text { (years) }\end{array}$ & Sex & Race & Family history & $\begin{array}{c}\text { Onset } \\
\text { (months) }\end{array}$ \\
\hline 1 & Wilkes $(1985)^{16}$ & 11 & M & American black & No & 6 \\
\hline 2 & Ivy $(1994)^{14}$ & 16 & M & American of Spanish & No & Sudden \\
\hline 3 & Hosoi $(1997)^{11}$ & 13 & M & Japanese & $\mathrm{HCM}$ & 4 \\
\hline 4 & Fukuda $(2003)^{13}$ & 13 & $\mathrm{~F}$ & Japanese & No & Sudden \\
\hline 5 & Flohr & 18 & $\mathrm{~F}$ & UC & IHD & Sudden \\
\hline 6 & Karaaslan $(2003)^{17}$ & 16 & M & Turk & No & Sudden \\
\hline 7 & Kobayashi $(2003)^{15}$ & 16 & $\mathrm{~F}$ & Japanese & VSA, KD, sudden death & Sudden \\
\hline 8 & $\mathrm{Li}(2005)^{18}$ & 17 & M & Chinese & No & Sudden \\
\hline 9 & Jefferies $(2005)^{19}$ & 13 & $\mathrm{~F}$ & American & No & Sudden \\
\hline 10 & Hasegawa $(2005)^{10}$ & 13 & M & Japanese & VT & Sudden \\
\hline 11 & Okajima $(2007)^{12}$ & 13 & $\mathrm{~F}$ & Japanese & No & 36 \\
\hline 12 & $\operatorname{Lim}(2007)$ & 6 & M & UC & AMI DL & Sudden \\
\hline 13 & Mori $(2008)^{20}$ & 14 & M & Japanese & No & Sudden \\
\hline 14 & Mori $(2008)^{20}$ & 11 & $\mathrm{~F}$ & Japanese & No & Sudden \\
\hline 15 & Odanaka $(2011)^{21}$ & 14 & $\mathrm{~F}$ & Japanese & No & Sudden \\
\hline 16 & Sueda $(2013)^{8}$ & 15 & $\mathrm{~F}$ & Japanese & No & 24 \\
\hline 17 & Sueda $(2013)^{7}$ & 13 & $M$ & Japanese & No & 12 \\
\hline 18 & Yamaguchi (2019) ${ }^{9}$ & 17 & M & Japanese & No & Sudden \\
\hline
\end{tabular}

\begin{tabular}{|c|c|c|c|c|c|c|}
\hline No. & $\begin{array}{c}\text { Chief } \\
\text { complaint }\end{array}$ & $\begin{array}{l}\text { Passive } \\
\text { smoking }\end{array}$ & Effort/rest & Timing & $\begin{array}{c}\text { Duration } \\
\text { (min) }\end{array}$ & ECG \\
\hline 1 & Chest $\mathrm{P}$ & UC & Rest & UC & $0.5-3$ & ST ele in V1-3, aVR, aVL \\
\hline 2 & Chest P & UC & Rest & Daytime & 60 & ST ele in II, III, aVF, V5-6 \\
\hline 3 & Chest OP & UC & Effort & Daytime & 5 & ST ele in aVL, V1-5 \\
\hline 4 & CPA & UC & Effort & Daytime & UC & Anteroseptal ischemia \\
\hline 5 & UC & UC & UC & UC & UC & UC \\
\hline 6 & Chest P & UC & Rest & Nighttime & 60 & ST ele in V5-6 \\
\hline 7 & Chest OP & UC & Rest/Effort & Daytime/nighttime & $2-3$ & No abnormality \\
\hline 8 & Chest P & UC & UC & UC & UC & ST ele in II, III, aVF \\
\hline 9 & Chest P & UC & UC & UC & UC & ST ele in II, III, aVF \\
\hline 10 & CPA & UC & Effort & Daytime & UC & ST ele in aVR, V1-3 \\
\hline 11 & Toothache & UC & UC & Daytime & UC & UC \\
\hline 12 & UC & UC & UC & UC & UC & Ischemia positive \\
\hline 13 & Chest OP & UC & Rest & Daytime (06:00 hours) & 150 & ST ele in I, aVL, V4-6 \\
\hline 14 & Chest P & UC & Rest & Nighttime (05:00 hours) & 180 & ST ele in V2-3 \\
\hline 15 & Chest P & UC & Rest & $\begin{array}{c}\text { Daytime } \\
\text { (06:00/12:00/15:00 hours)/ } \\
\text { nighttime }\end{array}$ & $10-30$ & ST ele in II, III, aVF, V3-6 \\
\hline 16 & Chest OP & UC & Rest & Nighttime & 5 & ST ele in II, III, aVF \\
\hline 17 & Chest OP & Yes & Rest/Effort & Daytime/Nighttime & $5-10$ & No abnormality \\
\hline 18 & Dyspnea & No & Effort & Daytime & UC & ST dep in III, aVF \\
\hline
\end{tabular}

AMI, acute myocardial infarction; Chest $P$, chest pain; Chest OP, chest oppression; CPA, cardiopulmonary arrest; DL, dyslipidemia; HCM, hypertrophic cardiomyopathy; IHD, ischemic heart disease; KD, Kawasaki disease; ST ele, ST elevation; ST dep, ST depression; UC, uncertain; VSA, vasospastic angina.

was detected in 8 patients, 1 patient had positive troponin $\mathrm{T}$ and 1 patient had elevated troponin I. Maximum elevated $\mathrm{CPK}<1,000 \mathrm{IU} / \mathrm{L}$ was found in 4 of 8 patients, and 1 patient had $>10,000$ IU/L CPK. Left ventricular wall motion abnormality was found in 6 patients, but 7 patients had no decreased left ventricular wall motion.

\section{Spasm Provocation Tests}

Spasm provocation tests were performed in 9 Japanese patients, but not in the other 11 patients. Intracoronary administration of acetylcholine (ACh) provoked diffuse spasm in all 9 patients. Both right and left coronary artery spasm provocation tests were performed in 5 patients. Multiple spasms occurred in 6 of 9 patients, and 3 patients had triple vessel spasm. 


\begin{tabular}{|c|c|c|c|c|c|c|c|c|}
\hline No. & $\begin{array}{l}\text { Cardiac } \\
\text { enzymes }\end{array}$ & UCG & CAG & ACh/ER & Spasm & Alive/dead & Medication & Complications \\
\hline 1 & Normal & $\begin{array}{c}\text { Septal } \\
\text { akinesia }\end{array}$ & Normal & Not done & UC & Alive & $\begin{array}{l}\text { Nifedipine } 10 \mathrm{mg} \\
\quad(3 \text { months })\end{array}$ & $\begin{array}{l}\text { Angina-free for } \\
14 \text { months }\end{array}$ \\
\hline 2 & $\begin{array}{c}\text { CPK } \\
349 \mathrm{IU} / \mathrm{L}\end{array}$ & Normal & Normal & Not done & UC & Alive & $\begin{array}{c}\text { Nifedipine/ } \\
\text { isosorbide dinitrate }\end{array}$ & None \\
\hline 3 & $\begin{array}{c}\text { CPK } \\
11,690 \mathrm{IU} / \mathrm{L}\end{array}$ & $\begin{array}{l}\text { Anterolateral } \\
\text { akinesis }\end{array}$ & Normal & $\begin{array}{l}\text { ACh } \\
(\mathrm{L} 100)\end{array}$ & $\begin{array}{l}\operatorname{LAD}(90) / \\
\operatorname{LCX}(95)\end{array}$ & Alive & UC & $\begin{array}{l}\text { AMI, VF, DC, } \\
\text { IABP, PCPS }\end{array}$ \\
\hline 4 & UC & UC & Normal & $\mathrm{ACh}$ & LAD/LCX & Alive & UC & $\begin{array}{l}\text { AMI, CPA, eNOS } \\
\text { abnormality }\end{array}$ \\
\hline 5 & UC & UC & UC & UC & Positive & Alive & UC & AMI, VSA \\
\hline 6 & $\begin{array}{c}\text { CPK } \\
905 \mathrm{IU} / \mathrm{L}\end{array}$ & Normal & Normal & Not done & UC & Alive & Verapamil 4 mg/kg & AMI, Ca-67 \\
\hline 7 & Normal & $\begin{array}{l}\text { Anterolateral } \\
\text { hypo LVG }\end{array}$ & Normal & $\begin{array}{l}\text { ACh } \\
(\mathrm{L} 100)\end{array}$ & LAD (d) & Alive & $\begin{array}{l}\text { Ca unknown } \\
\text { (20 months) }\end{array}$ & $\begin{array}{l}\text { Angina-free for } \\
20 \text { months }\end{array}$ \\
\hline 8 & Normal & Normal & Normal & Not done & UC & Alive & $\mathrm{Ca} /$ nitrate & None \\
\hline 9 & $\begin{array}{l}\text { Troponin I } \\
\text { elevated }\end{array}$ & UC & Normal & Not done & UC & Alive & UC & None \\
\hline 10 & Normal & LVH (apex) & Normal & $\begin{array}{c}\text { ACh } \\
\text { (L 50/R 50) }\end{array}$ & $\begin{array}{l}\text { RCA (d)/LAD } \\
\text { (d)/LCX (d) }\end{array}$ & Alive & $\begin{array}{l}\text { Ca/vasodilator/ } \\
\text { statin }\end{array}$ & VF, DC \\
\hline 11 & UC & $\begin{array}{l}\text { Lateral OMI } \\
\text { on autopsy }\end{array}$ & No stenosis & Not done & UC & Dead & None & $\begin{array}{l}\text { Marked intimal } \\
\text { hyperplasia }\end{array}$ \\
\hline 12 & $\begin{array}{l}\text { CPK/CK-MB } \\
\text { elevated }\end{array}$ & UC & Normal & Not done & UC & Alive & UC & None \\
\hline 13 & $\begin{array}{c}\text { CPK } \\
1,815 \mathrm{IU} / \mathrm{L}\end{array}$ & Normal & Normal & Not done & $\begin{array}{l}\text { Dilated after } \\
\text { ISDN }\end{array}$ & Alive & UC & None \\
\hline 14 & $\begin{array}{l}\text { Troponin } \mathrm{T} \\
\text { positive }\end{array}$ & Normal & Normal & $\begin{array}{c}\text { ACh } \\
(\mathrm{L} 50 / \mathrm{R} 50)\end{array}$ & LAD (d) & Alive & UC & None \\
\hline 15 & $\begin{array}{c}\text { CPK } \\
1,050 I U / L\end{array}$ & Normal & Normal & $\begin{array}{l}\text { ACh } \\
(\mathrm{L} 50)\end{array}$ & $\begin{array}{l}\operatorname{LAD}(d) / \\
\operatorname{LCX}(d)\end{array}$ & Alive & $\mathrm{Ca}$ & AMI \\
\hline 16 & $\begin{array}{c}\text { CPK } \\
407 \mathrm{IU} / \mathrm{L}\end{array}$ & Normal & Normal & $\begin{array}{c}\text { ACh } \\
\text { (R 50/L 100) }\end{array}$ & 8 (d) & Alive & $\mathrm{Ca}$ & AMI \\
\hline 17 & Normal & $\begin{array}{c}\text { Diffuse hypo } \\
\text { \%FS } 28\end{array}$ & Normal & ACh/ER/ERACh & $\begin{array}{l}\mathrm{RCA}(\mathrm{d}) / \mathrm{LAD} \\
\text { (d)/LCX (d) }\end{array}$ & Alive & $\begin{array}{l}\text { Diltiazem R } 100 \mathrm{mg} / \\
\text { nifedipine CR } 20 \mathrm{mg}\end{array}$ & None \\
\hline 18 & $\begin{array}{c}\text { CPK } \\
4081 U / L\end{array}$ & $\begin{array}{l}\text { Decreased } \\
\text { EF } 60 \%\end{array}$ & Normal & $\begin{array}{c}\text { ACh } \\
\text { (R 25/L 50) }\end{array}$ & $\begin{array}{l}\text { RCA (d)/LAD } \\
\text { (d)/LCX (d) }\end{array}$ & Alive & $\begin{array}{l}\text { Benidipine } 2 \mathrm{mg} / \\
\text { isosorbide } \\
\text { mononitrate } 20 \mathrm{mg} / \\
\text { nicorandil } 15 \mathrm{mg}\end{array}$ & $\begin{array}{l}\text { Decreased } \\
\text { LV }\end{array}$ \\
\hline
\end{tabular}

ACh, acetylcholine; AMI, acute myocardial infarction; $\mathrm{Ca}$, calcium-channel antagonist CAG, coronary arteriography; CPA, cardiopulmonary arrest; CPK, creatinine phosphokinase; (d), diffuse spasm; DC, direct current; EF, ejection fraction; eNOS; endothelial nitric oxide synthase gene; ER, ergonovine; FS, fractional shortening; Ga, gadolinium; IABP, intra-aortic balloon pumping; L, left; LAD, left anterior descending artery; LCX, left circumflex artery; LVH, left ventricular hypertrophy; OMI, old myocardial infarction; PCPS, percutaneous cardiopulmonary support; VF, ventricular fibrillation; VSA, vasospastic angina; R, right; RCA, right coronary artery; UC, uncertain; UCG, ultracardiography.

\section{Medications}

Calcium-channel antagonists were administered to 10 patients ( 2 for 1 patient; 1 for 9 patients), 4 patients had another vasodilator and there was no precise description of medications for the remaining 7 patients. Nitrates were administered to 2 patients.

\section{Complications and Prognosis}

In 6 cases the patient suffered from acute myocardial infarction and ventricular fibrillation occurred in 2 patients. Direct current was necessary to recover sinus rhythm for 2 patients. As cardiopulmonary support, intra-aortic balloon pumping and percutaneous cardiopulmonary support were necessary for 1 rescue patient. Endothelial nitric oxide synthase gene abnormality was found in 1 patient (case no. 4, Table 2): $\mathrm{T}^{-786} \rightarrow \mathrm{C}, \mathrm{A}^{-922} \rightarrow \mathrm{G}$, and $\mathrm{T}^{-1468} \rightarrow \mathrm{A}$ mutations in the $5^{\prime}$-flanking region on 1 allele. Overall, 1 patient died but the remaining 17 patients survived.

\section{Discussion}

Here we summarize the clinical data for adolescents less than 20 years old with VSA. A total of 6 patients had AMI and 1 patient died. In all 18 cases, a severe clinical state similar to refractory adulthood VSA was observed in the past. Cardiologists should cooperate with pediatricians to establish the diagnosis and treatment of adolescents with VSA.

\section{Pitfalls of Spasm in Adolescents}

If adolescent patients complain of chest pain, pediatricians and cardiologists may suspect mitral valve prolapse, myocarditis, or atypical chest pain. Although coronary artery spasm is involved in the pathogenesis of chest pain even in adolescents, we may infrequently encounter these young VSA patients. In this study, the majority of adolescents complained of chest pain or chest oppression, but cardiopulmonary arrest was the first attack in 2 adolescents, another complained just of toothache without chest symptoms and another patient had dyspnea on effort. Pediatricians and 
cardiologists should consider coronary artery spasm when an adolescent less than 20 years old complains of chest pain. Furthermore, cardiologists and pediatricians should question the adolescent's condition precisely.

\section{Spasm Provocation Testing in Adolescents}

Spasm provocation tests are necessary to diagnose the presence of coronary artery spasm in the clinic. We used the dose of pharmacological agents recommended in the JCS guidelines. When we perform ACh testing, we inject an incremental ACh dose of 20/50/100 $\mu \mathrm{g}$ into the left coronary artery and $20 / 50 \mu \mathrm{g}$ into the right coronary artery. Furthermore, the JCS guidelines recommend continuous administration of ergonovine (ER), not bolus injection. Cardiologists perform ACh or ER testing when diagnosing adult patients with VSA, whereas pediatricians are not familiar with performing these spasm provocation tests in the clinic. Pediatricians should perform these spasm provocation tests with trained cardiologists. The optimal maximum dose of ACh or ER in adolescents needs to be determined in order to perform the spasm provocation tests without irreversible complications.

\section{Medications}

Spontaneous remission is rarely observed in patients with VSA and sudden cardiac death can occur after self-cessation of medications by some with adult VSA patients. Medications including vasodilators in adolescents with coronary spasm will be life-long. However, we did not find a clinical course longer than 30 or 40 years periods for adolescents with VSA. Cardiologists should corroborate with pediatricians to ensure good quality of life and excellent outcomes for adolescents with VSA.

\section{Adolescents With Coronary Spasm in the Future}

Cardiologists and pediatricians should investigate coronary artery spasm in adolescents in the clinic, because coronary abnormal response has increased in Japanese patients, ${ }^{22}$ possibly with the widespread occurrence of metabolic syndrome, which has increased all over the world, even in adolescents.

Nakayama et al reported that the $\mathrm{T}^{-786} \rightarrow \mathrm{C}$ mutation in the $5^{\prime}$-flanking region of the endothelial nitric oxide synthase (eNOS) gene was associated with coronary spasm. ${ }^{23}$ We found 1 patient with that mutation. Genetic analysis including eNOS may help diagnose adolescents with VSA in the future. Cardiologists should also campaign to protect adolescents from secondhand smoke. Furthermore, many adolescents with non-variant angina or low disease activity VSA could be present clinically, so collaboration between pediatricians and cardiologists is essential for successfully treating adolescents with VSA in Japan.

\section{Funding}

None.

\section{Conflicts of Interest}

The authors declare that they have no conflicts of interest.

\section{References}

1. Yasue H, Takizawa A, Nagao M, Nishida S, Horie M, Kubota $\mathrm{J}$, et al. Long-term prognosis for patients with variant angina and influential factors. Circulation 1988; 78: 1-9.

2. Nakamura M, Takeshita A, Nose Y. Clinical characteristics associated with myocardial infarction, arrhythmias, and sudden death in patients with vasospastic angina. Circulation 1987; 75: $1110-1116$.

3. Sueda S, Kohno H, Oshita A, Izoe Y, Nomoto T, Fukuda H. Vasospastic heart failure: Multiple spasm may cause transient heart failure? J Cardiol 2009; 54: 452-459.

4. Igarashi Y, Yamazoe M, Suzuki K, Tamura Y, Matsubara T, Tanabe $\mathrm{Y}$, et al. Possible role of coronary artery spasm in unexplained syncope. Am J Cardiol 1990; 65: 713-717.

5. Sueda S, Kohno H. Impact of pharmacological spasm provocation test in patients with a history of syncope. Heart Vessels 2018; 33: $126-133$.

6. JCS Joint Working Group. Guidelines for diagnosis and treatment of patients with vasospastic angina (coronary spastic angina) (JCS 2013): Digest version. Circ J 2014; 78: 2779-2801.

7. Sueda S, Kohno H, Ochi N. Young 13 year old boy with vasospastic angina. J Jpn Coron Assoc 2013; 19: 355-360.

8. Sueda S, Kohno H, Sakakue T, Higaki T. Acetylcholine test is less sensitive to provoke coronary artery spasm in young rest angina patients: Limitations of single pharmacological spasm provocation tests. J Jpn Coron Assoc 2013; 19: 347-354.

9. Yamaguchi A, Kono T, Nakamura S, Kasano K, Yoshiwara H, Hattori E, et al. A case of 17-year-old men with vasospastic angina and low cardiac systolic function. Heart 2019; 51: 430-437 (in Japanese).

10. Hasegawa M, Taniguchi K, Sumitomo N, Hirano M, Abe O, Miyashita $M$, et al. Ventricular fibrillation in a 13 years boy with vasospastic angina. Heart 2005; 37: 170-174 (in Japanese).

11. Hosoi T, Koyama Y, Tange S, Sumino H, Kawai Y, Kumakura $\mathrm{H}$, et al. Acute myocardial infarction due to vasospasm in a 13-year-old boy. Jpn Circ J 1997; 61: 536-542.

12. Okajima Y, Hirai A, Higashi M, Harigaya K. Vasospastic angina in a 13-year-old female patient whose only symptom was toothache. Pedatr Cardiol 2007; 28: 68-71.

13. Fukuda N, Kurokawa S, Maeda K, Iseki S, Takahashi M, Niwano $\mathrm{H}$, et al. A young girl with vasospastic angina associated with mutation in endothelial nitric oxide synthase gene: A case report. Angiology 2003; 54: 233-237.

14. Ivy D, Kaye J, Flitter D, Wiggins J. Variant angina in an adolescent. Pediatr Cardiol 1994; 15: 45-47.

15. Kobayashi K, Kozuma R, Tsutsui M, Okazaki M, Tasaki H, Nakamura Y. Vasospastic angina in a 16-year-old female: Report of the youngest female patient and review of the literature. Circ $J$ 2004; 67: 467-469.

16. Wilkes D, Donner R, Black I, Carabello BA. Variant angina in an 11 year old boy. J Am Coll Cardiol 1985; 5: 761-764.

17. Karaaslan S, Baysal T, Baspinar O, Oran B. Adolescent with variant angina. Pediatr Int 2003; 45: 478-480.

18. Li JJ, Chu JM, Zhang CY. Variant angina in a 17 -year-old male. Acta Cardiol 2005; 60: 69-71.

19. Jefferies L, Tristman B. Prinzmetal in a teenage girl. Pediatr Cardiol 2005; 26: 486-487.

20. Mori T, Takehara K, TanakaK, Hiura M, Kitano K, Nakaima $\mathrm{O}$, et al. Acute myocardial infarction in teenagers: Two case reports. J Cardiol Jpn Ed 2008; 1: 159- 163 (in Japanese).

21. Odanaka Y, Okumura K, Ozaki N, Kishi K, Mori Y, Katayama $\mathrm{H}$, et al. Coronary spastic angina in two pediatric patients. Pediatr Cardiol Cardiac Surg 2011; 28: 56-64.

22. Sueda S, Kohno H, Oshita A, Fukuda H, Kondou T, Yano K, et al. Coronary abnormal response has increased in Japanese patients: Analysis of 17 years' spasm provocation tests in 2093 cases. J Cardiol 2010; 55: 354-361.

23. Nakayama M, Yasue H, Yoshimura M, Shimasaki Y, Kugiyama $\mathrm{K}$, Ogawa $\mathrm{H}$, et al. $\mathrm{T}^{-786 \rightarrow} \mathrm{C}$ mutation in the 5'-flanking region of the endothelial nitric oxide synthase gene is associated with coronary spasm. Circulation 1999; 99: 2864-2870. 